\title{
Preliminary Study of Zinc Removal from Cyanide-free Alkaline Electroplating Effluent by Precipitation using Oxalis Plants
}

\author{
D. BENOUALI ${ }^{1 *}$, S. KHERICl ${ }^{2}$, M. BELABBASSI ${ }^{1}$, \\ M.M. BELKANDOUCl ${ }^{1}$ and A. BENNEMRA ${ }^{1}$ \\ 'Department of Physical Chemistry, Faculty of Chemistry, USTO- Algeria. \\ 2Department of Industrial organic Chemistry, Faculty of Chemistry, USTO- Algeria. \\ ${ }^{*}$ Corresponding author E-mail: benouali2001@yahoo.fr \\ http://dx.doi.org/10.13005/ojc/300215
}

(Received: April 05, 2014; Accepted: May 15, 2014)

\begin{abstract}
The aim of this study is the reduction of Zinc from the cyanide-free alkaline zinc-plating effluent. Various methods utilized for removing or recovering the heavy metals are adsorption, chemical precipitation, sedimentation filtration, reverse osmosis etc. We are interested in using oxalis plant as a potential chelating/settling agent for the treatment of electroplating effluent collected from a local industrial unit. Oxalis pes-capae has an exceptionally high content of oxalic acid which is known as moderate and week chelating agent. The efficiency of the performance oxalis powder (KITININ) was estimated and the optimum dose was determined using conductivity, volumetric, atomic absorption spectroscopy and $\mathrm{pH}$ measurements. The results show the performance of oxalis in treating $\mathrm{Zn}$ plating effluent effectively. In effect, a white crystalline precipitate of zinc oxalate is easily extracted $(98,52 \%$ elimination of $\mathrm{Zn})$ and a high settling rate is observed. The maximum zinc uptake by Oxalis in batch systems is estimated to $6,44 \mathrm{mg} / \mathrm{g}$.
\end{abstract}

Key words: Oxalis, precipitation, Zinc, Electroplating effluent.

\section{INTRODUCTION}

Today, developed industries can use more than $40 \%$ of total water, leading to more water quality problems. The metal pollutants can originate from a variety of sources: Metal finishing and electroplating processes. The plating baths contain high concentrations of potential polluting metals. The rinse water has a low concentration of heavy metals but, can contribute to significant load because of their large volumes. In addition only 30$40 \%$ of all metals used in the electroplating process can be effectively plated onto the articles ${ }^{1}$. Its residual waste effluents are responsible for the supply of toxic and corrosive heavy metals to the environment. So, a number of treatment techniques have been developed and are utilized for heavy metal removal or recovery ${ }^{2}$, because of the slow natural process of metal formation (metals are considered to be a nonrenewable resource) and 
their toxic effects ${ }^{3,4}$. These points have clearly explained the importance of fixing some limits for these heavy metals in drinking and waste waters. Treatment methods to reach the fixed limit (5ppm) include chemical precipitation and other separation methods $^{5-12}$. In this study we are interested in the treatment of the cyanide-free alkaline zinc-plating effluent, where cyanide may be replaced by complexing or chelating agents such as sodium gluconate, triethanolamine or polymeric amines. The resulting baths present therfore problems with waste treatment. A second generation of organic addition agents eliminated chelating agents was developed in industry and most of the currently available processes have eliminated these problems with the use of an entirely new family of organic reaction products ${ }^{13}$ but zinc removal from dilute solution remains a problem. Many researchers have studied various natural and synthetic chelating agents for their ability to remove heavy metals from electroplating effluents. Chelating agents (organic acids) are the most popular extracting reagents used for soils decontamination ${ }^{14,15}$. Oxalate compound used to precipitate metal ions from solutions, oxalate-treated activated carbons was also used for the adsorption of $\mathrm{Co}$ and $\mathrm{Ni}$ from aqueous solutions ${ }^{16}$. The aim of the present study is to assess the potential of a natural, low molecular weight organic acid, oxalic acid for zinc removal from electroplating effluent. This aliphatic organic acid exists naturally form relatively stable complexes with metals and has a greater potential to mobilize $\mathrm{Zn}$ from aqueous effluent in its insoluble zinc oxalate form. Indigenous to South Africa, Oxalis pes-caprae is an invasive plant in many other parts of the world, including Algeria and it can contain up to $16 \%$ of the dry weight as oxalic acid, present in both photosynthetic and non-photosynthetic tissues ${ }^{17}$. The present study provides general guide lines for the removal of dissolved $\mathrm{Zn}$ metal from cyanide-free electroplating effluent using oxalis plant in a powder form (KITININ) estimated as a potential chelating/settling agent.

\section{MATERIAL AND METHODS}

The electroplating effluent used in the experiment was taken from a local electroplating unit. It consists of a dilution of a cyanide-free alkaline electroplating bath, where temperature and $\mathrm{pH}$ were determined using $\mathrm{pH}$ meter. A suitable volume was taken before the dilution and was analyzed by volumetric method, using complexion III and indicator eriochrom Black T, buffer tampon $\mathrm{pH} 10$. At the equivalence point, color changes from red to net blue. $1 \mathrm{ml}$ complexion III (0.05M) corresponding to $3,2685 \mathrm{mg}$ of $\mathrm{Zn}^{13}$.

Oxalispes-caprae were harvested from the field, stored and dried at room temperature. After complete drying of the plant, it was grounded to fine powder. Next, the obtained powder was washed by an appropriate solvent to eliminate chlorophyll. Finally, the particles which supposed to be poor of oxalic acid were separated by a mechanical method. Content of oxalate anion was analyzed by volumetric method with potassium permanganate $0,1 \mathrm{Nat} 80^{\circ} \mathrm{C}$, in the presence of sulfuric acid $4 \mathrm{~N}$ under magnetic stirring. At equivalence point, the solution became colorless. $1 \mathrm{~mL} \mathrm{KMnO}_{4} 0,1 \mathrm{~N}$ corresponds to $4,4 \mathrm{mg}$ of $\mathrm{C}_{2} \mathrm{O}_{4}{ }^{2-}[2]$. The $\mathrm{pH}$-metric titration of the raw and treated oxalis powders were carried out for the estimation of the oxalate anion and the free oxalic acid content and to confirm mechanic purification efficiency.

After dilution of the electroplating bath solution with demineralized water, Zn concentration metal content was $140 \mathrm{mg} / \mathrm{L}$. Three liters of this solution were prepared and stored for experiments. A volume of $100 \mathrm{~mL}$ was then taken in a beaker $(250 \mathrm{~mL})$ and $10 \%$ suspension of treated oxalis powder (KITININ) was added gradually with agitation at a speed of $50 \mathrm{rpm}$ at room temperature. After treatment, $\mathrm{Zn}$ was measured by Atomic Absorption Spectroscopy.

\section{RESULTS AND DISCUSSION}

The electroplating cyanide-free alkaline solution bath taken from a local electroplating unit was analyzed for the quantitative determination of $\mathrm{Zn}$ metal and sodium hydroxide contents. $\mathrm{Zn}$ was found to be $25 \mathrm{~g} / \mathrm{L}$ and the concentration of $\mathrm{NaOH}$ rang of $125 \mathrm{~g} / \mathrm{L}$. A quantity of this concentrated solution was diluted by adding demineralized water to $140 \mathrm{mg} / \mathrm{L}$ of $\mathrm{Zn}$ metal and the final $\mathrm{pH}$ was 11,09 . The residual concentration of cations in electroplating effluent can be taken into account apart from $50-100 \mathrm{mg} / \mathrm{L}$ up to $5-6 \mathrm{~g} / \mathrm{L}$ according to 


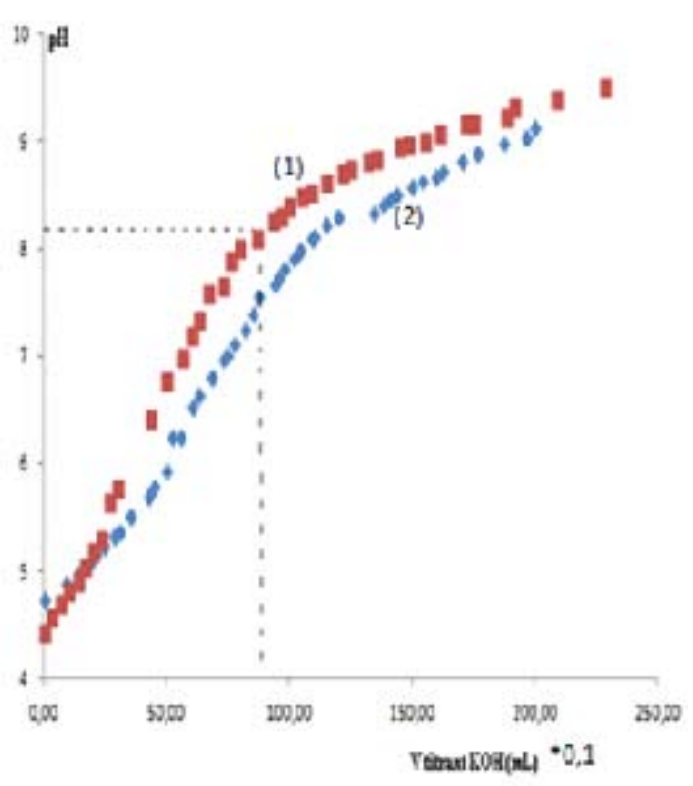

Fig. 1: $\mathrm{pH}$-titration curve of $2 \mathrm{~g}$ Oxalis powder (KITININ) (1) and $2 \mathrm{~g}$ raw oxalis powder (2) in $100 \mathrm{~mL}$ distilled water with $\mathrm{KOH}(0,4 \mathrm{~N})$

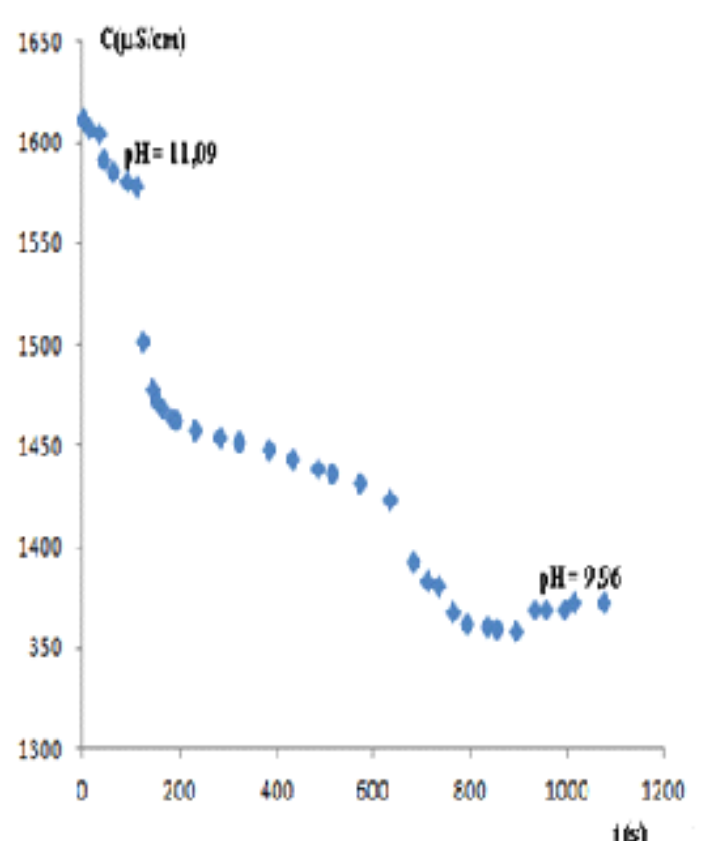

Fig. 3: Evolution of conductivity versus added oxalis powder mass

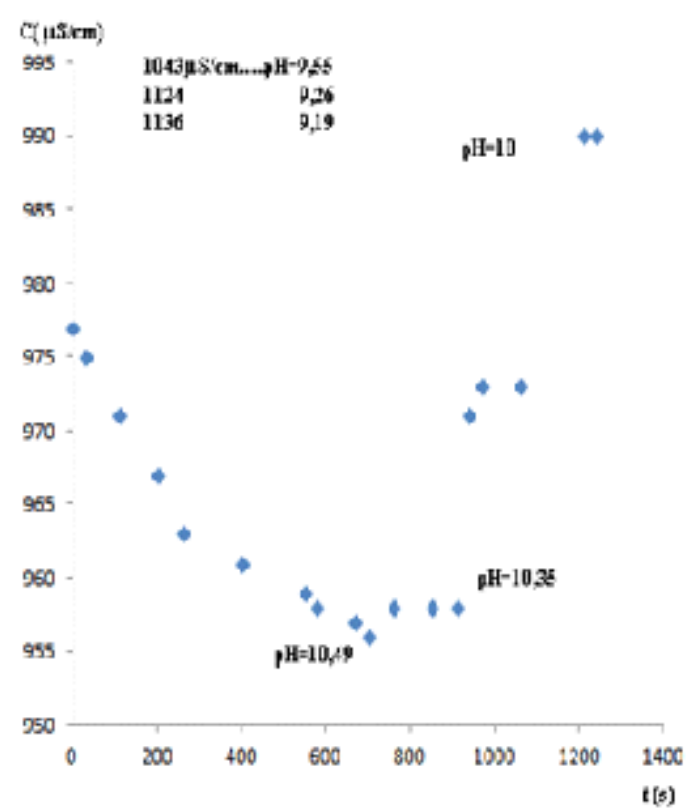

Fig. 2: Evolution of conductivity and $\mathrm{pH}$ versus added oxalis powder mass

reference 2. On the other hand, after washing the prepared oxalis powder (KITININ) with an appropriate solvent, the green color corresponding at chlorophyll molecules was successfully eliminated. After drying, the powder was yellow color and particles supposed to be poor of oxalic acid were separated by mechanical method on basis of density. Content of oxalate anion in treated oxalis powder was analyzed by volumetric method with potassium permanganate, and concentration of $130 \mathrm{mg} / \mathrm{g}$ was obtained. $\mathrm{A} \mathrm{pH}$-metric titration with $\mathrm{KOH}(\mathrm{O}, 4 \mathrm{~N})$ of the raw and treated oxalis powder was carried out (figure 1). When free oxalic acid is titrated with a strong base $(\mathrm{KOH})$, the titration curve has two equivalence points. These correspond to the removal of each successive proton from the diacid, and occur at $\mathrm{pH} 2.71$ and $\mathrm{pH} 8.36$.

From the titration curves it is clear that the oxalic acid is in its monometallic form (mono potassium salt) as the initial $\mathrm{pH}$ corresponds to the end of the first half-neutralization. The $\mathrm{pH}$ of a suspension of $2 \mathrm{~g}$ of treated oxalis powder becomes more acidic than the crude oxalis powder, but the equivalent volume is almost the same. According to the equivalent volume around $9 \mathrm{~mL}$, the concentration of mono potassium oxalate in the 
treated powder oxalis (KITININ) is estimated at $12 \%$. The oxalic acid content in oxalis plant was usually about $16 \%$ of the dry weight according to reference ${ }^{17}$

Up on the addition of oxalis suspension, the flockscoalesced and settled down immediately and the $\mathrm{Zn}$ elimination was monitored with conductivity measurement. In effect, if the divalent $\mathrm{Zn}$ interacts with oxalic acid present in there soluble form and adsorbed by the plant tissues, it is compulsory that the conductivity decreases. The latter was decreased with added mass of oxalis powder, due to the mobilization of $\mathrm{Zn}$ as oxalates as shown in figure 2 . The main part of heavy metal $(\mathrm{Zn})$ was removed from the sludge, the suspensions were centrifuged at $3000 \mathrm{rpm}$ for $5 \mathrm{~min}$ and the supernatant was then filtered for $\mathrm{Zn}$ analysis using absorption spectrometry (AAS). The results show about $98,56 \%$ of zinc removal.

In our experiment zinc was removed by precipitation as metal insoluble complex, and oxalis powder can be considered as a flocculent agent. Determining the effectiveness of ourbio-chelating agent for $\mathrm{Zn}$ removal from electroplating cyanidefree effluent has commonly been accomplished in one-step batch extractions at the laboratory-scale. Such extractions often encounter some limitations and difficulties :reverse reactions and delayed precipitation.

In a first test (Figure 2) the optimum dose has been exceeded in order to neutralize the effluent after zinc mobilization. But the addition of an excess of powder oxalis had a low effect on $\mathrm{pH}$ adjustment as the $\mathrm{pH}$ in the vicinity of the optimum dose was decreased from 11 to 10.49 . By adding advantage of oxalis powder, the conductivity of the treated oxalis powder increased gradually to 1043 , 1124 and $1136 \mu \mathrm{S} / \mathrm{cm}$ for a $\mathrm{pH}$ reduction only equal to $9.55,9.26$ and 9.19 respectively. Therefore a correction of the $\mathrm{pH}$ was necessary using a mineral acid, such as hydrochloric or sulfuric.

The effect of the $\mathrm{pH}$ on the removal of $\mathrm{Zn}$ must be examined because the waste water from plating factory was of various $\mathrm{pH}$ values. In our study, effluent samples were used without $\mathrm{pH}$ adjusting. Usually, the optimum $\mathrm{pH}$ values for $\mathrm{Zn}$ precipitation range is $8-10$. From the experimental figure 3 of conductivity versus oxalis powder dose, it was evident, that $\mathrm{pH} 10$ was optimum for complexation of $\mathrm{Zn}$ with oxalic acid and 5-6 g/L of KITININ is sufficient for the treatment of zinc electroplating cyanide-free effluent concentration ranging from 100 to $150 \mathrm{mg} / \mathrm{L}$ of $\mathrm{Zn}$ metal.

\section{ACKNOWLEDGMENTS}

We Acknowledgment assistance from the AFAK CONTROL Laboratory, Oran-Algeria for AAS analysis

\section{CONCLUSION}

A simple and cost effective treatment procedure was proposed for the removal of zinc from zinc plating industry effluent using oxalis plant in its powder form. The most important thing is that the Zinc recovery ions process with 98,52\% efficiency. The low zinc oxalate solubility product value is an advantage for the treatment by complexation/flocculation/settling and filtration of waters with zinc ion content. Using this method, it is not only possible to remove the Zinc from the cyanide-free alkaline electroplating effluent but also to recover the transitional metal $(Z n)$. Zinc oxalate adsorbed on organic plant oxalis powder could be turn into oxide. This work is an attempt to develop new bio chelating/flocculent agent for heavy metals removal from dilute solutions and to the reduction of zinc, chrome, lead etc to very low concentration less than $5 \mathrm{ppm}$.

\section{REFERENCES}

1. Grebenyuk V.D.; Sorokin G.V.; Verbich S.V.; Zhiginas L.H.; Linkov V.M.; Linkov N.A.; Smit J.J. Water S. 1996, 2 : 381-384.

2. Gavris G.; Cozma A.; Ursu M-P; Petrehele A.
Nonconventional Technology Review. 2009, 2: 32-35 .

3. Mukesh P.; Lokendra S. T. Animal and Environmental Sciences. 2013, 3,3,143-157. Xiaoyun L.; Xiuling C.; Xiumin C. 2012, 3, 4, 
562-566.

5. Bernard E.; Jimob A. Interntional journal of engineering and applied sciences. 2013, 4(2): 95-102.

6. Kanawade S. M.; Gaikwad R.W. International journal of chemical engineering and applications. 2011, 2(3): 199-201.

7. Santhosh P.; Sridevi A. J. Environ. Res. Develop. 2013, 8(1): 102-108.

8. Abdel-Ghani1 N. T.; El-Chaghaby G. A. International Journal of Latest Research in Science and Technology. 2014, 3(1): 24-42.

9. Adhoum N.; Monser L.; Bellakhal N.; Belgaied J-E. Journal of Hazardous Materials B, 2004,112: 207-213.

10. Vishal M., Appl. Water Sci. 2014; 1-22.

11. Al-Hemiri A. A. ; Heaven E. M. Iraqi Journal of chemical and Petroleum Engineering. 2010, 11(1): 11-19.

12. Yongabi K. A. International review of chemical engineering. 2009; 2(3): 444-458.

13. Budman E. Metal Fnishing, 1995, 60-64.

14. Oustan S.; Heidari S.; Neyshabouri M.R.; Reyhanitabar A., Bybordi A. International Conference on Environment Science and Engineering. 2011, 8.

15. Jong-Oh Kim; Yong-Woo Lee; Jinwook Chung. KSCE Journal of Civil Engineering. 2013, 17(7): 1596-1602.

16. Kqsqini H.; Kebana P.T.; Saghti A. A.; Bolton K. Engineering and Technology 1963, 76: 707-721.

17. Millerd A.; Morton R. K.; Wells J. R. E. Biochem. J. 1963, 86: 57. 